\title{
耐火被覆を有する建築鋼部材の リユースに関する施工実験
}

\section{TRIAL CONSTRUCTION TEST ON REUSE OF BUILDING STEEL STRUCTURAL MEMBERS WITH FIRE- PROOFING PROTECTION}

\author{
藤田正則 — $* 1$ \\ 岩田 衛—— - * 3 \\ キーワード : \\ 建築鋼部材, リユース, 耐火被覆, 試施工, 下地調整
}

Keywords:

Building steel structural member, Reuse, Fire-proofing protection, Trial construction, Surface preparation

Masanori FUJITA $-* 1$
Mamoru IWATA $-* 3$

Atsushi SHIBUYA — $* 2$

The reuse system mentioned in this paper is an overall system for realizing a reuse business in a series of cyclic process in a reuse flow, namely, design, fabrication, construction, maintenance, dismantling, and storage. Here, we take up building steel structural members not only with non proofing protection but also with proofing protection. Whether structural members with fire-proofing protection are adaptable or not for reuse is discussed when building steel structures are dismantled. Fire-proofing protections are classified, and its application for reuse of building steel structural members with fire-proofing protection is evaluated through trial construction test.

\section{1. はじめに}

建築分野においても地球環境問題への対応が求められる中，日本 建築学会では様々な取り組み ${ }^{1) \sim 8)}$ を行っており, その一環としてカ 一ボンニュートラル化を目指した建築関連分野の地球温暖化対策ビ ジョン2050を提言している ${ }^{9)}$ 。著者らは，環境負荷削減を目指して 建築鋼構造分野においてリユースシステムに関する研究を行ってい る10) 13)。鋼材のリユースが既存の流通と同様に循環するため，従 来の生産・製品の供給という「動脈産業」に対して, その処理, 再生 利用, 再使用を行う「静脈産業」の確立を目指している。既報におい ては，基本検討項目である 1) リユースビジネス調查 ${ }^{14) ~ 17) ， 2 ~} 2$ ) デ ータベースの構築方法 $\left.{ }^{18)} \sim 19\right) ， 3$ ) ストックヤードの設置方法 ${ }^{20)}$, 4) リュース材の加工方法 ${ }^{21)}$ ，5 ) リユース材の性能評価 ${ }^{22) ~ 25) ， 6 ~) ~}$ 丁寧な解体方法 ${ }^{26)} ， 7$ ) リユース材に関するガイドライン 27) 28)，8 ) リユースに関する技術開発 ${ }^{29)}$ などを報告している。これらの研究 は, 既存ストックにおいて, 無耐火被覆の工場や作業場, 倉庫など を対象にしてリユースシステムの構築を目指したものである。一方 では，耐火被覆を有する建築鋼構造も多く, リユースの可能性を並 行して検討する必要がある。

建築基準法では，建物の階数に応じて $1 \sim 3$ 時間耐火とその階数 に応じて主要構造部材が定められた時間以上の加熱に耐えるように 規定されている。住宅や事務所を除く 3 階建て以上の特殊建築物は 耐火構造となり, 建築鋼構造においても耐火被覆を必要と寸る状況 にある。

本論文では，耐火被覆を有する建築鋼部材のリユースとしての適 用の可能性を試施工により検討するものである。まず，建築鋼部材
の耐火被覆工法を分類し，耐火被覆の取付け・取外しの容易性，部 材の損傷の程度を試施工により比較する。さらに, 而火被覆の取外 し後の建築鋼部材の表面下地について検討する。

\section{2. リュース用部材と耐火被覆工法}

\section{1 リュース用部材}

ここで想定するリユースの対象部材は，日本工業規格（以降，JIS 規格という)などにより部材サイズが体系化された鋼材 (将来, リュ 一スされる予定の部材を以降，リユース用部材という)としている。 リユース用部材の採取の対象建築物は, リユース材に関するガイド ライン ${ }^{25)}$ において, 主に鉄鋼メーカーによりプレハブ化された無耐 火被覆の工場や作業場，倉庫などとしている。リユース用部材を使

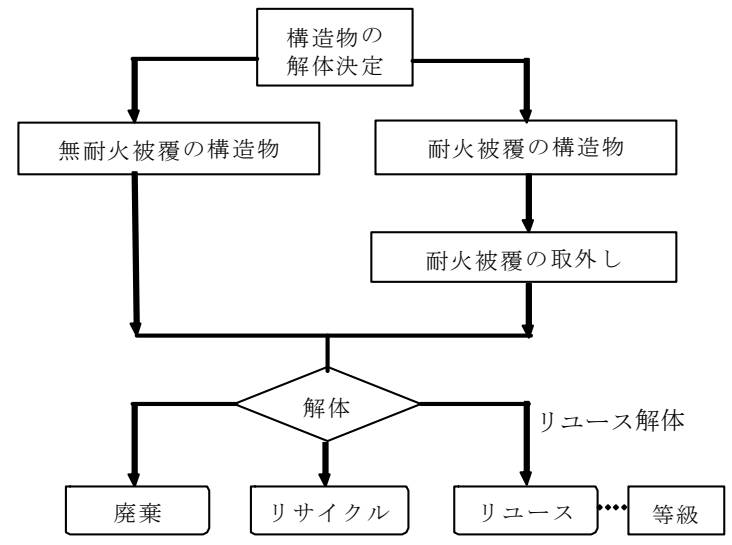

図 1 耐火被覆の有無とリユース用部材

\footnotetext{
山口大学大学院理工学研究科 教授・博士 (工学)

（干 755-8611 山口県宇部市常盤台 2 丁目 16-1)

2 山口大学大学院理工学研究科 大学院生

神奈川大学工学部建築学科 教授・工博
}

\footnotetext{
Prof., Graduate School of Science and Engineering, Yamaguchi Univ., Dr. Eng.

Graduate Student, Graduate School of Science and Engineering, Yamaguchi Univ. Prof., Dept. of Architecture and Building Engineering, Kanagawa Univ., Dr. Eng.
} 
用する対象建築物は用途や期限付き建築物, 短期間使用建築物, 恒 久建築物などの使用期間によっても異なる。このうち, 耐火被覆を有 する構造物は図 1 に示すように解体前に耐火被覆の取外しの工程を 追加する。耐火被覆の取外し後, リユース解体工法により部材の大 部分がリユースされるのに対して, 従来の解体工法の場合, そのほ とんどがリサイクルされる。工場・作業場などの構造物より採取さ れたリユース用部材は無耐火被覆であるため, 無耐火被覆の構造物 または耐火被覆の構造物への適用がある。これに対して, 耐火被覆 を有する構造物は, 部材の損傷の程度, 耐火被覆の取付け・取外し の容易性によってはリユース用部材の等級も劣る可能性がある。一 方, リュースの対象となる建物は竣工後 30 年以上経過しているもの が多く, アスベスト対策などの技術開発が喫緊の課題であろう。

\section{2 要求性能}

耐火被覆を有する建築鋼部材をリユース寸るにあたって下記の 要求性能が挙げられる。

1 ）耐火被覆の取外し時に, 建築鋼部材に損傷を与えないこと。

耐火被覆の取外しの際，建築鋼部材に損傷が無いか，あるいは軽 微であることが必要である。建築鋼部材の損傷が軽微であれば, リ ユース用部材として利用しやすい。

2 ) 耐火被覆の取付け・取外しが容易であること。

建築鋼部材の耐火被覆の取付け・取外しが容易であれば, リユー ス用部材として適用しや寸い。また, 耐火被覆の取外し後, 建築鋼 部材の表面に残存した耐火被覆が少なければ，下地調整が容易にな る。

\section{3 耐火被覆エ法のタイプ}

建築鋼部材の耐火被覆には, 吹付け, 巻付け, 成形板張り, 左官,

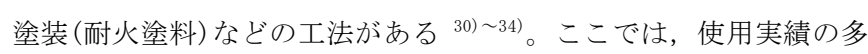
い吹付け工法, 巻付け工法, 成形板張り工法を取り上げる。仕様規 定に基づく耐火被覆の選定フローを図 2 に示す。なお，性能規定に 基づく耐火設計においては, 火災性状と鉄骨温度を予測し, 架構の 安全性を検討して耐火被覆を選定する。地域(防火・準防火), 用途, 区画, 階数などによって, 耐火時間が規定され, 耐火被覆の厚さ・ 所要量が設定されている。

1 ) タイプ 1 (巻付け工法)

巻付け工法には, ロックウール系やセラミックファイバー系の材 料の耐火被覆をファスナーを用いてスタッド溶接により取付けもの がある。吹付けのように下地防錆塗料の種類を選ばず, カッターナ

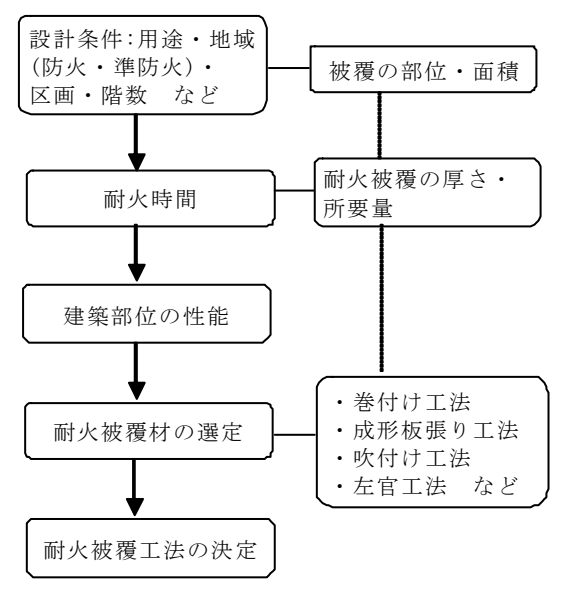

図 2 耐火被覆の選定フロー

イフなどで簡単に加工できる。乾式工法のため, 材料の養生期間が 不要であり, 施工時の粉塵も少ないため, その他の業種との並行作 業ができる。

2 ) タイプ 2 (成形板張り工法)

繊維混入けい酸カルシウム板などの材料による乾式の成形板張 り工法で, 材料の養生期間が不要であり, 施工時の粉塵も少ないた め, その他の業種との並行作業ができる。

3 ) タイプ 3 (吹付け工法)

吹付け工法は, 耐火被覆を現場にて圧送・吹付ける工法である。 不定形の材料を対象物に吹付けることにより，複雑な下地にも継ぎ 目の無い一体化した耐火被覆層を形成できる。

\section{3. 耐火被覆を有する建築鋼部材の試施工}

建築鋼部材の耐火被覆の取付けと取外しが部材のリユースに与 える影響について試施工により検討する。

\section{1 対象モデル}

耐火被覆を有する建築鋼部材のリユース評価にあたって, 対象と したモデルは 5 スパン 10 層のサステナブルビル構造29)で, その縮尺 は1/5である。試験体の床伏図・軸組図を各々図 3 に示す。サステナ ブルビル構造の 1 ユニット（コーナー部）を代表として取り出して いる。耐火被覆の材料として2.3に示した, ケース $1 \sim 3$ の 3 種類を 取り上げる (表 1 )。なお, 実構造物との縮尺の相違による作業性は 異なる部分もあると推定されるが, ここでは相対比較とする。耐火 被覆の厚さは1時間耐火を想定してタイプ 1 において厚さ $25 \mathrm{~mm}$, タイ

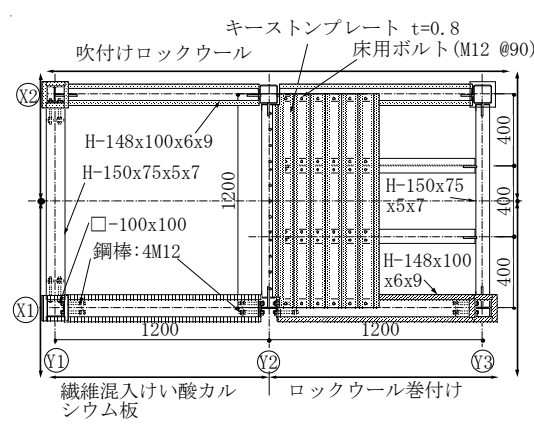

(a) 床伏図

図 3 試験体の伏図・軸組図 (単位: $\mathrm{mm}$ )

表 1 耐火被覆の仕様

\begin{tabular}{|c|c|c|c|c|}
\hline & 耐火被覆 & \begin{tabular}{c|} 
厚さ \\
$\mathrm{mm}$
\end{tabular} & $\begin{array}{l}\text { 密度 } \\
\mathrm{kg} / \mathrm{m}^{3}\end{array}$ & $\begin{array}{c}\text { ファスナー径 } \\
\mathrm{mm}\end{array}$ \\
\hline タイプ 1 & $\begin{array}{l}\text { ロックウール(酸化ケイ素・酸 } \\
\text { 化カルシウム系鉱物繊維板) }{ }^{* 1}\end{array}$ & 20 & $80 \sim 150$ & $\phi 2$ \\
\hline タイプ 2 & 繊維混入けい酸カルシウム板 & 20 & $350 \sim 470$ & $\phi 2$ \\
\hline タイプ 3 & $\begin{array}{l}\text { 吹付けロックウール (セメント } \\
\text { を含む) }{ }^{* 2}\end{array}$ & 25 & $280 \sim$ & --- \\
\hline
\end{tabular}

注 *1 フェルト状に成形した耐熱ロックウールに不織布 (難 燃材) を接着。

*2 吹付けロックウール: JIS A 9504 (人造好物繊維保温板) の規格品, セメント:JIS R 5210 (ポルトランドセメント) ・吹付けロックウールの配合割合：ロックウール (60土 $5 \%)$, セメント $(40 \pm 5 \%)$ 
プ 2 とタイプ 3 において $20 \mathrm{~mm}$ とする。タイプ 1 とタイプ 2 の耐火被 覆の形状は $1 / 5$ 縮尺を考慮して幅 $182 \mathrm{~mm}$ とし, そのファスナー ( $\phi 2$ ) の留付けピッチは $50 \mathrm{~mm}$ である。タイプ 1 のファスナーは先端が鋭利 なピンにワッシャが付いているもので, スタッド溶接による留付け である（図 4)。タイプ 2 のファスナーは建築鋼部材の下地材に釷に て留付ける。また, タイプ 3 の耐火被覆の厚さは, 吹付け厚さ確認 ピンで管理する(図 5 )。

\section{2 耐火被覆の取付け}

サステナブルビル構造の耐火被覆の取付けは従来のラーメン構 造と概放同じであり，図 6 の取付けフローに示すように鉄骨造の建 方終了後, 柱・梁の順とする。タイプ 1 およびタイプ 2 においては 割付図を基に耐火被覆のプレカットを行う。各ケースとも柱の下方 から上方に向かって順次, 耐火被覆を取付ける。タイプ 1 およびタ イプ 2 の耐火被覆の割付は柱の下方より上方, 梁の端部より一方向 とし, 最終の割付で調整する。ただし, タイプ 3 の場合, 吹付けに あたって方向性が無いものの, 比較のため吹付順序は他のケースと 同じとする。耐火被覆の取付け状況を図 7 に示す。タイプ 1 の耐火 被覆は, フランジ上端にファスナーをスタッド溶接により留付ける。 タイプ 2 の耐火被覆は接着された下地を介して釘で留付ける。ケー ス 2 の耐火被覆を留付ける際, 柱や梁の使用部位とその留め付け姿 勢によっては, ファスナーの留付け角度にばらつきが生じた。タイ プ 2 の場合, 梁フランジの下端の耐火被覆は横向き姿勢の他, 上向 き姿勢によりファスナーを留付ける箇所があるのに対して, タイプ 1 の耐火被覆を巻付ける際に, 梁上端のファスナーを横向き姿勢で 留付けるためである。タイプ 3 に関しては, 耐火被覆の吹付け終了 後に表面のけば立ちを押さえるため, 表面をコテならし後, 厚さ確 認用のピンを使用して, 柱・梁の各部位の 5 箇所の断面を測定し, 所定の耐火被覆の厚さ以上であることを確認した。タイプ 3 に関し

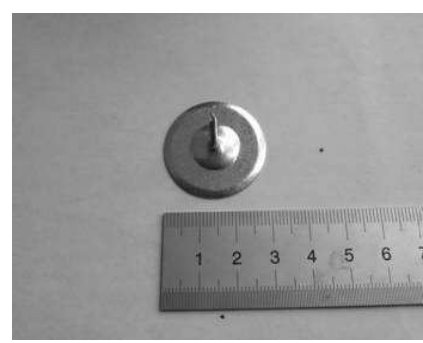

図 4 ファスナー(タイプ 1 )

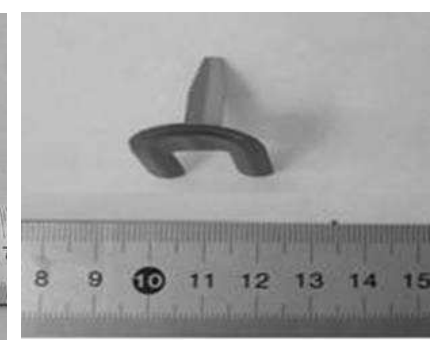

図 5 厚さ確認ピン(タイプ 3 )

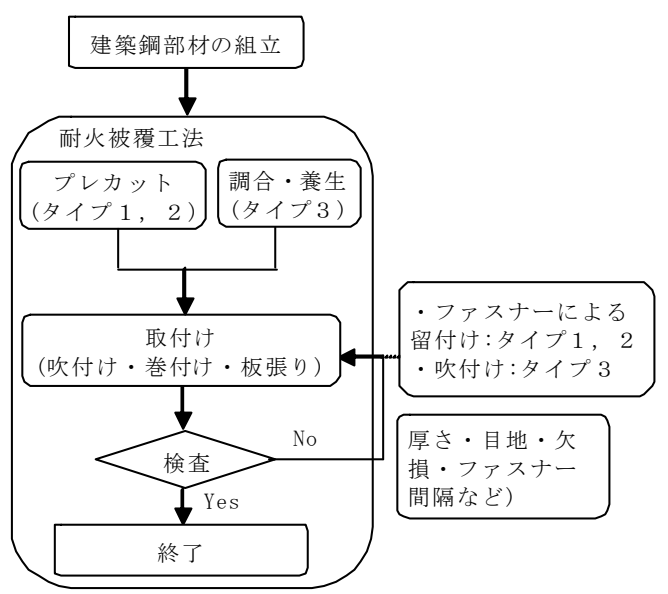

図 6 耐火被覆の取付けフロー
て耐火被覆の代表的な厚さの測定結果である1層部分を図 8 に示す。 耐火被覆の吹付け厚は, 認定厚さ $25 \mathrm{~mm}$ に対して $31 \sim 60 \mathrm{~mm}$ の範囲にば らついている。耐火被覆の厚さのばらつきはあるものの, 継ぎ目の 無い耐火被覆層とすることができた。

\section{3 耐火被覆の取外し}

耐火被覆の取外しには, あらかじめ部材の耐火被覆を全て除去し て, その後, 鋼構造部材を解体する方法や耐火被覆を飛散させない ように囲い込む方法なざがある。除去された耐火被覆はいずれも分 別・回収された後, 最終処分場にて処理される。ここでは, 前者の 方法によるものとし, 耐火被覆を取付けて約 2 ケ月間の養生後に, 取外しを行う。サステナブルビル構造の耐火被覆は, 各タイプとも 建築鋼部材の梁・柱の順に取外す。耐火被覆の取外し状況, 取外し 後の建築鋼部材の表面下地を各々図 9 , 図 10 に示す。タイプ 1 とタ イプ 2 においては耐火被覆のファスナーに対して切断工具, タイプ 3 においてはヤスリ, コテなどを使用する。タイプ1の場合, ファ スナーを切除した際, 建築鋼部材の表面にスタッド溶接痕跡が生じ ている。このため, スタッド溶接痕をグラインダー処理し, 建築鋼部 材の表面を平坦にする。タイプ 2 に関して, ファスナーは成形板の 下地材に留付けているために, 建築鋼部材の損傷は無いものの, 耐火

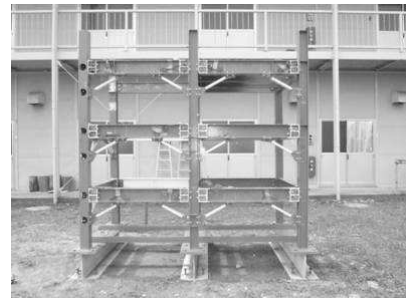

(a)サステナブルビル構造

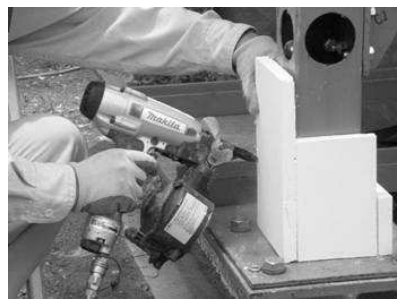

(c) タイプ 2

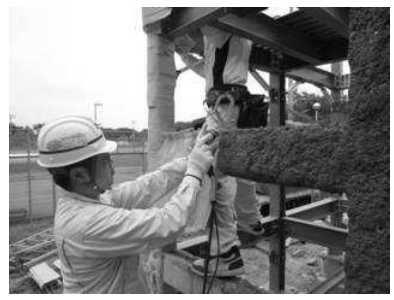

(b) タイプ 1

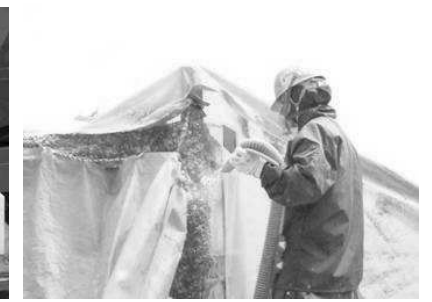

(d) タイプ 3

図 7 耐火被覆の取付け状況

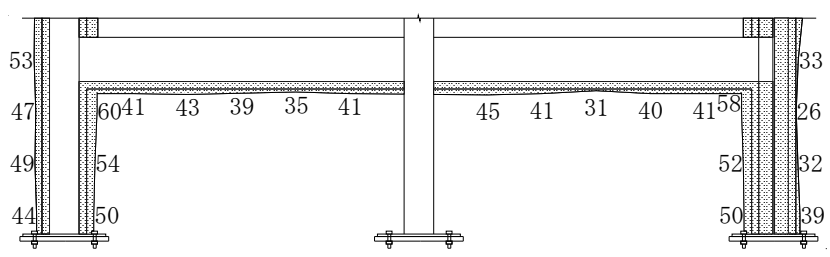

(a) 軸組図

単位:mm

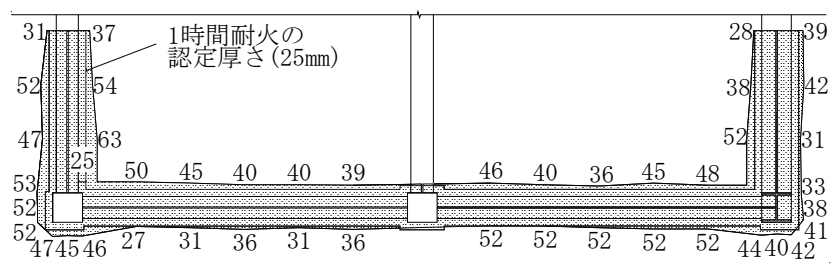

(b) 伏図単位:mm

図 8 タイプ 3 の耐火被覆の厚さの測定結果 (1 層) 
被覆用下地の接着痕が部分的に生じている。タイプ 3 に関して, 柱 と梁の接合部, ガセットプレート, リブプレートが取り合う箇所で は, 耐火被覆が残存している。また, 耐火被覆を取外した際の塗装 剥離も部分的に生じている。このように耐火被覆を有する建築鋼部 材において, タイプ1においてはファスナーのスタッド溶接痕, タ イプ 2 においては下地材の接着痕, タイプ 3 においては, 耐火被覆 が付着しているものの, 各タイプの建築鋼部材の損傷は無い。なお, タイプ 1 に関してピンのスタッド溶接による建築鋼部材のシャルピ 一衝撃值, 引張強さ, 硬さなどの物性に与える影響は無視できるこ とが報告されている35)。

これらのことから建築鋼部材は耐火被覆の取外しにより部材の 表面下地は異なるものの, 損傷が無く健全である。

\section{4 耐火被覆の取付け，取外しにおける考察}

各タイプの耐火被覆の取付けの比較を表 2 に示す。タイプ 1 およ びタイプ 2 の場合, 割付図に基づいて取付けるものの, 柱・梁接合 部, 座屈拘束部材の接合部, 耐火被覆の割付端部に現場において耐

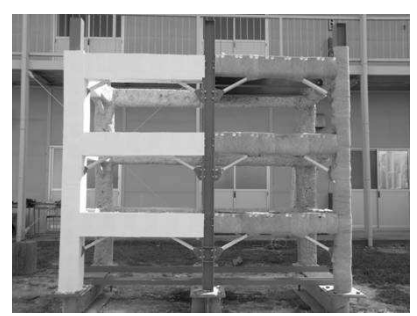

（a）解体前の耐火被覆

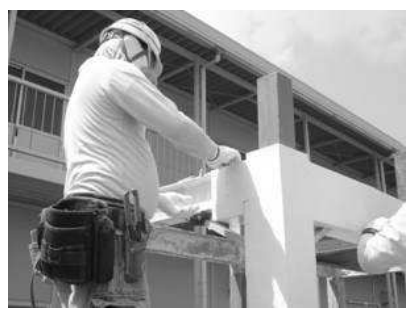

(c) タイプ 2

図 9 耐火被覆の取外し状況
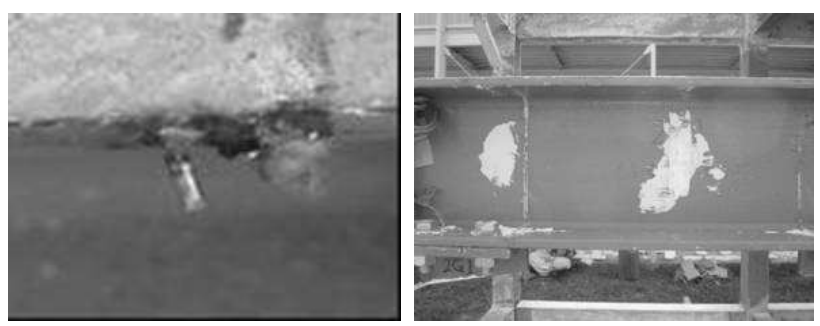

(a)スタッド溶接痕 (タイプ 1)（b）下地の接着痕 (タイプ 2)
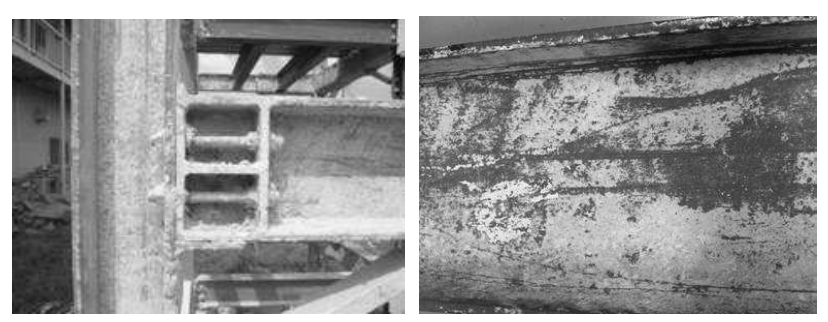

(c) 耐火被覆の接着痕 (タイプ 3 , 左: 接合部, 右:一般部) 図 10 而火被覆の取外し後の建築鋼部材
火被覆の切欠きが生じている。これに対して, タイプ 3 においては 取付けに方向性が無く, 耐火被覆の連続性が確保できている。また, コテならし後, セメントスラリーを吹付けて耐火被覆の表面を硬化 させることで，発塵を防止することができた。

各タイプの耐火被覆の取外しの比較を表 3 に示寸。タイプ 3 の取 外し時にロックウールやセメントの多くの浮遊粉塵が生じるものの, タイプ 2 においては軽微である。また, タイプ 1 , タイプ 2 の耐火 被覆の取付けの際の浮遊粉塵は, タイプ 3 に比べてほとんじ生じて いない。

タイプ 1 とタイプ 2 の取外し時間は建築鋼部材の見付け面積当 りで比較すると概ね等しい。また, タイプ 3 はタイプ 1 の 2 倍程度 である。耐火被覆を有する建築鋼部材において, 各タイプとも耐火 被覆の取外しは可能であるものの, 取外しの容易性においては作業 効率や養生の有無において差異が見られた。

\section{5 建築鋼部材の下地調整}

ここで，海外において使用実績の多いショットブラストによる下 地調整を試みる。耐火被覆の取外し後, ショットブラスト前後の建 築鋼部材の表面下地を図11に示す。左半分がタイプ 3, 右半分がタ イプ 2 の耐火被覆である。ショットブラストはエアーブロー方式(シ ヨットの大きさ: $\phi 0.6 \sim 1.4 \mathrm{~mm})$ により建築鋼部材の表面の肌荒しを 行う。建築鋼部材のリユース回数は $1 \sim 2$ 回を想定しており，カスケ 表 2 各タイプの取付けの比較

\begin{tabular}{|c|c|c|c|}
\hline タイプ & $\begin{array}{c}\text { ファスナーの } \\
\text { 取付け姿勢 }\end{array}$ & \multicolumn{1}{|c|}{ 検査項目 } & 取付け状況 \\
\hline タイプ 1 & 横向き & $\begin{array}{l}\text { 耐火被覆のたるみ, 告, 目地・ファスナー } \\
\text { の間隔 }\end{array}$ & 浮遊粉塵は無し \\
\hline タイプ 2 & 横向き・上向き & $\begin{array}{l}\text { 耐火坡覆の欠損, 目 } \\
\text { 地・ファスナの間 }\end{array}$ & 浮遊粉塵は軽微 \\
\hline タイプ 3 & -- & 耐火被覆の厚さ & 浮遊粉塵が多い \\
\hline
\end{tabular}

表 3 各タイプの取外しの比較

\begin{tabular}{|l|l|l|l|}
\hline タイプ & 取外し状況 & 養生 & 取外し後の建築鋼部材の外観 \\
\hline タイプ 1 & $\begin{array}{l}\text { 浮遊粉塵はほ } \\
\text { とんど無し }\end{array}$ & 不要 & ファスナー切除後のスタッド跡 \\
\hline タイプ 2 & $\begin{array}{l}\text { 浮遊粉塵は軽 } \\
\text { 微 }\end{array}$ & $\begin{array}{l}\text { 必要 } \\
\text { (簡易) }\end{array}$ & 耐火被覆の下地切除後の接着跡 \\
\hline タイプ 3 & 浮遊粉塵は多い & 必要 & $\begin{array}{l}\text { 耐火被覆が全体的に部材表面に } \\
\text { 付着 }\end{array}$ \\
\hline
\end{tabular}
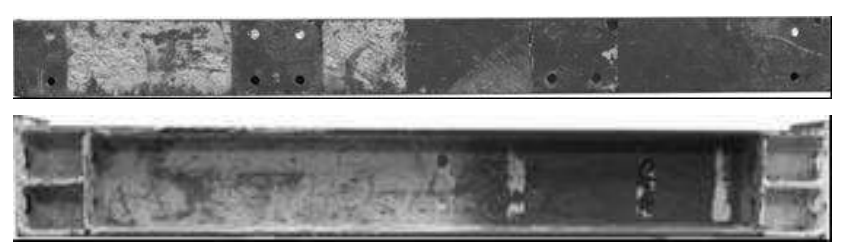

(a) 耐火被覆の取外し後(上 : 梁フランジ面, 下: 梁ウェブ面)

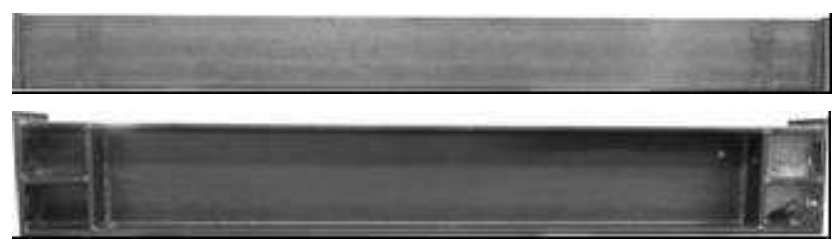

(b)ショットブラスト終了後(上 : 梁フランジ面, 下 : 梁ウェブ面) 図 11 耐火被覆の下地調整 (中央より左: タイプ 3 , 右:タイプ 2) 
ード化は考慮していない。各タイプ共にショットブラストによる下 地調整 ( 1 種B)により, 耐火被覆はほとんど残存していない。タイプ 3 の接合部においては，1／5縮尺であることも影響し，スチフナが 取り合うため, 耐火被覆がわずかに残存している。なお，電動バフ による下地調整も同様に可能であることを確認している。

これらのことから，耐火被覆を有する建築鋼部材は各タイプ共に ショットブラストによる下地調整により，新材と同様の素地が確保 できる。

\section{4. おわりに}

本論では, 耐火被覆を有する建築鋼部材のリユースの可能性を検 討するために試施工を行った結果，下記のことが明らかになった。

1 ) 建築鋼部材は耐火被覆工法のタイプによって耐火被覆の取外し 後の表面下地は異なるものの，健全である。

2 )タイプ 1, タイプ 2 の耐火被覆の取付けにおいては方向性がある ため, 現場での切欠きが生じる。

3 )各タイプの耐火被覆の取外しの作業効率や養生の有無において 差異がみられる。

4 )耐火被覆を有する建築鋼部材は, 各タイプ共にショットブラスト により，新材と同様の素地が確保できる。

\section{謝辞}

本研究にあたり，山口大学工学部感性デザイン工学科学生 (当時) 川合翔二氏の協力を得ました。また，ニチアス(株)清水玄宏氏には 試験体の協力を得ました。記して深く感謝致します。

\section{[参考文献]}

1 ) 日本建築学会編：地球環境建築の寸寸め, 彰国社, 2009.9

2 ) 秋山 宏, 伊香賀俊治, 木俣信行 : 地球環境問題への建築学会としての取 り組みと展望, 建築雑誌 Vol. 114, No. 1445, 日本建築学会, 1999.10

3 ) 日本建築学会構造委員会 鋼構造運営委員会: 建築鋼構造における環境性 とは何か, 日本建築学会大会 構造部門パネルディスカッション, 2002.8

4) 日本建築学会 地球環境委員会:2050 年に向けた建築の地球温暖化対策, 日本建築学会大会 (東北) パネルディスカッション, 2009.8

5 ) 日本建築学会 :「建築部材のリユースマニュアル・同解説」, 2009.10

6 ) 日本建築学会 構造委員会 鋼構造運営委員会: 鋼構造による新構造シス テム開発の現状と今後の展望, 日本建築学会大会（東北）パネルディスカ ッション, 2009.8

7 ) 日本建築学会 長寿命建築構造特別研究委員会 地球環境委員会: 建築物 長寿命化のための課題と提案, 日本建築学会大会 (東北) パネルディスカ ッション, 2009.8

8 ) 日本建築学会 地球環境委員会: 低炭素社会の実現に向けて建築構造分野 はどう進むべきか 日本建築学会大会 (北陸) パネルディスカッション， 2010.9

9 ) 日本建築学会 : 建築関連分野の地球温暖化対策ビジョン 2050 , カーボン ニュートラル化を目指して，2009. 12

10) 岩田 衛, 堂野前等, 久松雄治: 建築鉄骨構造のライフサイクルにおける 環境負荷削減のシナリオとその評価，日本建築学会構造系論文集，第 533 号, pp. 167-173, 2000.7

11) 山田 哲, 黒川礼子, 會澤貴浩, 岩田 衛: 廃棄物量と LCCO2 量に着目 し た鉄骨造建物における環境負荷の評価，日本建築学会構造系論文集，第 554 号, pp. 131-137，2002.4

12) 岩田 衛, 竹内 徹, 藤田正則: 建築鋼構造のシステム化, 鋼構造出版, 2001. 2

13) Masanori FUJITA, Mamoru IWATA: Reuse System of Building Steel Structures, STRUCTURE \& INFRASTRUCTURE ENGINEERING, Vol.4, No.3, Taylor \&
Francis, pp.207-220, 2008.6

14) 岩田 衛，藤田正則，前田親範: 情報技術を利用した建築鋼構造のリユー スマネジメントモデルの提案, 総合論文誌第 1 号「地球環境建築のフロン ティア」学術論文, 日本建築学会, pp. 81-86, 2003.2

15) 藤田正則, 文蔵亮介，岩田 衛: 建築鋼構造のリユースシステムに関する 研究 -リユース材のストック-, 日本建築学会環境系論文集, 第 618 号, pp. 95-101，2007.7

16) 藤田正則, 岡本康司, 中村裕幸, 岩田 衛: 建築鋼構造のリユースシステム にする研究 - IC タグを利用したリユースビジネスモデルの提案-, 日本建 築学会環境系論文集, Vol.74 第 638 号, pp. 531-537, 2009.4

17) 岡本康司, 藤田正則, 岩田 衛: 建築鋼構造のリユースシステムに関する 研究 -二酸化炭素排出量の推定-, 日本建築学会環境系論文集, 第 75 巻 第 652 号，pp. 535-542，2010.6

18) 藤田正則, 前田親範，小河利行，岩田 衛 : 建築鋼構造のリユースシステ ムに関する研究 -データベースの構築方法の提案-, 日本建築学会環境系 論文集，第 587 号, pp. 93-98,2005. 1

19)藤田正則，山下拓三，関戸宏幸，小河利行，岩田 衛：建築鋼構造のリユ ースシステムに関する研究 -リユース材の適用シミュレーション-, 日本 建築学会環境系論文集，第 612 号, pp. 111-116, 2007.2

20) 藤田正則, 前田親範, 岩田 衛: 建築鋼構造のリユースシステムに関する 研究 一ストックヤードの設置方法の提案-, 日本建築学会環境系論文集, 第 579 号, pp. 105-110, 2004. 5

21) 藤田正則, 文蔵亮介, 岩田 衛: 建築鋼構造のリユースシステムに関する 研究 -リユース材の加工とその性能評価-, 日本建築学会環境系論文集, 第 620 号, pp. 97-102, 2007.10

22) Masanori FUJITA, Mamoru IWATA: Reuse dismantling and structural performance of reusable members, Structural Engineering International SEI Vol.18, pp.230-237, 2008.8

23) 藤田正則, 前田親範, 岩田 衛: 建築鋼構造のリユースシステムに関する 研究 -リユース材の構造性能-, 日本建築学会環境系論文集, 第 600 号, pp. 83-89, 2006. 2

24) 藤田正則, 村井正敏, 文蔵亮介, 岩田 衛: 建築鋼構造のリユースシステ ムに関する研究 -リユース材のストック診断-, 日本建築学会環境系論文 集, Vol. 73 第 630 号, pp. 1061-1067, 2008.8

25) 藤田正則, 村井正敏, 岩田 衛: 建築鋼構造のリユースシステムに関する 研究 一既存ストックにおけるリユース材の等級-, 日本建築学会環境系論 文集, Vol. 76 第 669 号, pp. 1025-1031，2011.11

26) 藤田正則, 田中繁樹, 岩田 衛: 建築鋼構造のリユースシステムに関する研 究 -低層鉄骨造の丁寧な解体方法-, 日本建築学会環境系論文集，第 604 号, pp. 109-114, 2006.6

27) 藤田正則, 岡本康司, 村井正敏, 岩田 衛: 建築鋼構造のリユースシステ ムに関する研究 -リユース材に関するガイドラインの提案とその検証実 験-, 日本建築学会環境系論文集, 第 643 号 Vol. 74, pp. 1107-1114,2009.9

28) Masanori FUJITA, Mamoru IWATA: Guideline for reusable members of building steel structures and test, International Association for Bridge and Structural Engineering, Codes in Structural Engineering Developments and Needs for International Practice, pp.545-552, 2010.5

29) 藤田正則, 村井正敏, 前田親範, 岩田 衛: 建築鋼構造のリユースシステ ムに関する研究 -サステナブルビル構造の試施工によるリユースの検証 -, 日本建築学会環境系論文集, 第 75 巻 第 656 号, pp. 923-928, 2010.10 30) 日本建築学会 : 構造材料の耐火性ガイドブック, 2009. 3

31) 作本好文：鉄骨耐火の新材料と新工法, 彰国社, 1994.9

32) 耐火被覆工法研究会: 鉄骨造の耐火被覆工事 工法と施工, 彰国社, 1995.1

33) 日本建築学会 : 建築工事標準仕様書 JASS 6 鉄骨工事, 2008.4

34) 日本建築学会 : 建築工事標準仕様書 JASS18 塗装工事, 2006. 11

35) 大貫寿文, 近藤照夫 : 巻付け系耐火被覆用固定ピンが鉄骨の物性に与える 影響, 日本建築学会関東支部研究報告集, pp73-76, 2005. 3

[2011 年 6 月 19 日原稿受理 2011 年 10 月 14 日採用決定］ 